\title{
CONTATO IMPROVISAÇÃO por Nancy Stark Smith
}

Nancy Stark Smith ${ }^{1}$ Mayana Marengo

Tradução de Stephan Baumgärtel ${ }^{3}$

Mayana: Antes de tudo, quero agradecer a sua disposição em conceder esta entrevista. A primeira pergunta, Nancy, é quando foi que você percebeu que o contato improvisação (CI) estava se tornando uma técnica de dança, uma técnica de improvisação em dança.

Nancy: De certa forma, não foi uma questão de perceber que era uma técnica. Era uma prática que estava se espalhando, as pessoas a praticavam e entre eles eram alguns bailarinos. E aqueles que eram bailarinos ficaram estimulados e inspirados em sua prática enquanto coreógrafos, professores e bailarinos. Ou seja, não é que ela se tornou uma técnica. Era uma prática com muitos aspectos. Alguns deles eram técnicos, outros de cunho improvisacional, outros composicional ou estéticos. E havia muitos

1 Nancy Stark Smith, inicialmente ginasta, passou a estudar dança moderna e pósmoderna no início dos anos 1970, muito influenciada pela dança e a improvisação realizada pela Grand Union e pelos avanços da Judson Dance Theater da década de 1960, em Nova York. Em 1972, ela dançou nas primeiras apresentações de Contato Improvisação em Nova York e desde então esta prática tem sido fundamental para o seu desenvolvimento como dançarina, professora, artista, escritora editora, trabalhando exaustivamente ao longo dos anos com Steve Paxton e outros. Em 1975, co-fundou a Contact Quarterly, um veículo de idéias em movimento e revista de improvisação que ela continua a co-editar e produzir com Lisa Nelson. Seu primeiro livro, Caught Falling: The Confluence of Contact Improvisation, com David Koteen, foi publicado em 2008. Seus escritos também aparecem no livro Taken by Surprise: A Dance Improvisation Reader, publicado pela Wesleyan University Press. Criou UNDERSCORE, uma Jam Session estruturada de contato improvisação.

Acadêmica do curso de Licenciatura em Teatro da UDESC e pesquisadora de Contato Improvisação. Nancy Stark Smith cedeu esta entrevista no dia 12/12/2011. Foi filmografada no Galpón de Guevara, 326 Bairro de Guevara - Cidade de Buenos Aires. outros níveis que os bailarinos podiam usar conforme seus interesses. Então, não é que ela foi purificada até ser uma técnica específica. Nem acho que é isso hoje. As pessoas usam o contato improvisação de modo muito diferente.

Mayana: Então, você não pensa nessa dança como um tipo de técnica?

Nancy: Penso que ela oferece um modo de trabalhar com o corpo e com o corpo do outro que possui aspectos técnicos. Penso que há habilidades, há princípios que podem ser aplicados a muitas coisas. Mas não penso que é uma técnica, não. Com certeza possui elementos que são muito úteis para o treinamento de bailarinos.

Mayana: Dentro desse contexto de treinamento, de adquirir habilidades e assimilar princípios, qual é sua opinião sobre aquilo que podemos chamar de rigor. Onde você colocaria este aspecto?

Nancy: Rigor está na atitude, não na atividade. É um engajamento completo. É mental e físico. Penso que as pessoas podem praticar as habilidades sem rigor ou praticá-las com rigor. Mas o contato improvisação enquanto atividade exige muito. Exige muita tensão e prontidão física.

Mayana: Nancy, gostaria que você refletisse um pouco sobre a ideia de uma ética dentro do contato improvisação. Como você entende a questão da ética dentro desse contexto? 
Nancy: O que você quer dizer com ética? Você poderia definir o que significa ética para você? Sabe, eu não posso responder a esta pergunta até entender o que você quer dizer com essa palavra. Ética, em minha língua, implica em julgamentos de valor. Tem a ver com a forma correta de comportar-se. Então, se você faz algo ético, é a coisa certa a ser feita.

Mayana: Não, isso para mim é uma questão moral. Não é sobre isso que quero falar.

Nancy: Talvez você coloque a questão em outros termos.

Mayana: Bom, vamos continuar e talvez voltemos a este ponto depois a partir de outro ângulo. A minha próxima pergunta é sobre os diferentes modos como as pessoas se apropriaram do contato improvisação nos diversos lugares no mundo inteiro.

Nancy: Ora, aqui, apropriar é a palavra importante. Porque apropriar-se significa pegar algo e usar de modo diferente. Então, você se refere ao "espalhar" do contato improvisação, às diferentes formas como as pessoas fazem o $\mathrm{CI}$, ou você quer dizer que elas a usam para outra coisa?

Mayana: Ora, isso é parte do problema ético sobre o qual eu queria conversar. Porque usar o contato improvisação para, vamos dizer, objetivos terapêuticos, é uma coisa. Mas inventar um processo terapêutico com elementos do contato improvisação e dizer que estamos fazendo CI é algo bem diferente.

Nancy: Sim, eu entendo. Bom, eu não sou a policial supervisionando esse trabalho e não quero sê-lo. Eu o faço de um modo que me interessa e estou interessada nos modos como outras pessoas o usam e desenvolvem. As pessoas usam o CI para finalidades terapêuticas, o usem em sua prática enquanto terapeutas, e até enquanto seres humanos as pessoas encontram nele algum benefício terapêutico, físico, emocional ou social. Eles estão usando o CI com um objetivo social, simplesmente para estar com outras pessoas e curtir. Ou elas pegam as ideias e fazem uma coreografia. $O$ contato improvisação está sendo usado na educação, para treinar bailarinos, ou simplesmente para se movimentar, o usam com crianças ou pessoas de terceira idade. Sabe, é algo livre.

Acredito que encontramos a ética, no sentido em que uso a palavra, no modo como o contato improvisação está sendo usado e no modo como está sendo descrito. Do tipo, isso é uma coisa boa ou a coisa certa a fazer? Penso que usar algo que você valoriza e desenvolvê-lo, isso é algo livre, algo natural. Mas se você adapta essa palavra em muitas formas diferentes, e se alguém que estuda contigo não pode participar de uma Jam em algum outro lugar do mundo e dançar lá com alguém, então você perdeu a língua, o central dessa língua. Há dialetos em uma língua, há pronúncias diferentes em uma língua, há aplicações dessa língua, há diferentes tipos de conversas que as pessoas têm entre elas. Algumas são estéticas, algumas são pessoais, outras são físicas, muitos tipos de conversa. Mas se você nem consegue falar com alguém, porque você perdeu a língua, porque alguém te disse que aquilo que estavam falando era contato improvisação enquanto, de fato, era outra coisa, então o processo foi longe demais. Entretanto, aplicar os princípios de diversos modos, é natural. Talvez você queira usar um pouco de contato improvisação num contexto terapêutico e - está funcionando!

Mayana: Mas isso não significa defender o contato improvisação enquanto um método terapêutico, ou afirmar que se trata de uma expansão de sua consciência ou de uma liberação de sua sexualidade. 
Nancy: Ora, há interpretações diferentes. Diria que o que você colocou são interpretações amplas. Isso é a experiência que essas pessoas têm, e depois elas dizem que o trabalho é isso. No entanto, é a sua experiência que é isso. Há muitas pessoas e situações diferentes e ninguém vai obrigar a deixar desenvolver sua própria prática de modos diferentes. Novamente, se ela se afasta longe demais da essência, talvez caia fora.

Mayana: A minha questão acerca da ética era sobre este ponto em que as pessoas perdem o contato com a prática física central.

Nancy: Eu diria que a prática física é o elemento central. Penso que isso já é muito bem estabelecido. Mas para onde as pessoas vão com esse elemento, até onde eles vão e ainda pensam que é contato improvisação, isso é diferente em cada lugar. As pessoas que queiram focar um determinado modo de usar, elas vão fazê-lo. Mas novamente, se você pega uma dessas pessoas e a coloca a dançar com uma pessoa que está trabalhando a dimensão física, então você terá uma conversa interestante. 